\title{
Post-qualitative design research: Negotiating serendipity and risking the colonised self
}

\author{
Karolien Perold-Bull \& Elmarie Costandius \\ Stellenbosch University \\ Corresponding Author: karolien@sun.ac.za
}

(Submitted: 27 February 2019; Accepted: 31 May 2019)

\begin{abstract}
The research discussed in this paper aimed to explore design education in the context of transformation in South African higher education through practising design research/education geared at productive change within a specific institution. Through experimentation with a postqualitative methodological approach, processes of subjectification that transpired throughout the doing of a specific case of design/research/teaching in the context of the institution's Visual Communication Design curriculum were critically negotiated. Experimentation with representational praxis in ways that challenged its traditional semiotic function allowed space and time for subjects to become more attuned to recognising and responding to serendipitous moments within their situated present. It can, consequently, be argued that the more such moments become felt through everyday design education and practice, the more receptive individuals can become to the potential for productive future change.
\end{abstract}

Keywords: design education, design research, post-qualitative, serendipity, transformation

\section{Introduction}

Given the capitalist nature of contemporary society, design is often regarded as a practice solely geared at the production of tangible products (Brassett and Marenko, 2015). Such a perspective on the field of design is, however, limited. The 1969 definition of design by Herbert Simon - that "[e]veryone designs who devises courses of action aimed at changing existing situations into preferred ones' (cited in Brassett and Marenko, 2015: 11) - opens space for the material, social, and discursive dimensions of design to work together. Design is positioned as an abstract activity or process that can include the production of physical objects as well as multi-sensory experiences. Brassett and Marenko (2015: 12) have held that such descriptions of design clearly position it as a 'future-oriented' process geared at 'materialising the "not yet" now'. As Brassett (2015: 33) says, '[d]esigning things (products, processes, systems, garments, images, experiences, and so on) involves the material coagulations of affects, stories, and issues, with insight, foresight and hindsight inserted in their many folds.' 
Design, thus, is a field in flux. We believe its inherent ontological nature - 'how the designed goes on designing' (Willis, 2006: 93) - is the reason for this. From this perspective, we have to acknowledge how we have been designed and contribute to designing the world in multidimensional ways. Such designing involves the complex interplay of global, as well as local, forces. Globally, we are living in the age of the Anthropocene, a geological era in which human life is having significant impact on the earth in a geological sense (Chakrabarty, 2009). As Davis and Turpin (2015) argue, this has taken shape because of either/or thinking as a defining feature of dominant global ideology', and '[r]epresentationalism, metaphysical individualism, and humanism work hand in hand, holding this worldview in place' (Barad, 2007: 134). In the context of South Africa, this has been manifested in colonialism, and later in apartheid, both of which have demonstrated that an ontology based on dualistic logic can have disastrous effects because of 'the ways in which such divides are treated culturally, particularly the hierarchies established between the pairs of each binary, and the social, ecological, and political consequences of such hierarchies' (Escobar, 2012: 24). Despite having officially made space for differences to exist on an equal level, South Africa is still in the process of dealing with the social, political, material, and affective consequences of coloniality today. This can be explained, in part, because of dualistic logic being so strongly ingrained in our society's conscience on an ontological level. To work towards productive change with the same logic that has bred difference in the past is counterintuitive. In the current post-apartheid context, especially in terms of higher education, this has, for example, led to numerous processes intended to affect positive change resulting in re-essentialising and reinvigorating difference (Langa, 2017; Murris, 2016; Shay and Peseta, 2016). Active efforts at decolonisation are hampered by persistent inequalities ingrained into institutional systems and structures. Rather than maintaining the logic of the past, serendipity - the development of yet unknown processes of future change (Apple Dictionary, 2018) - is called for. There is no other position than this, we believe, from which design can start its work.

Thinking about design in this manner has direct implications on how one goes about doing research in the field. According to Faste and Faste (2012, n.p.), 'while typical research tends to have the goal of narrowing its focus towards specific solutions to well-defined problems, design research ${ }^{2}$ often results in a broadened understanding of the problem domain and many alternative potential solutions.' To ensure its active negotiation of future potential, design research must thus necessarily be risky. It should actively work at allowing space for happy accidents to occur and direct the process. In this paper, we discuss a specific case of

\footnotetext{
${ }^{1}$ Davis and Turpin (2015: 7) extend the description of the Anthropocene by arguing that the devastation that characterizes the Anthropocene is not simply the result of activities undertaken by the species Homo sapiens, instead, these effects derive from a particular nexus of epistemic, technological, social, and political economic coalescences figured in the contemporary reality [which] represents the heightened hierarchical relations of humans, the continued violence of white supremacy, colonialism, patriarchy, heterosexism, and ableism, all of which exacerbate and subtend the violence that has been inflicted upon the non-human world.'

${ }^{2}$ In this context, the term "design research" refers to research in the broad field of design; not to the design of research in a methodological sense.
} 
post-qualitative design research done in the context of transformation in South African higher education, specifically in the field of design. We argue that experimentation with postqualitative methodology in the field of design holds productive future potential. It can allow for creative research practices that do not aim at the easy extraction of meaning from findings but are directed at the troubling of that which seems to make easy sense. It can allow for serendipity in an increasingly controlled research environment and facilitate attunement and considered response to such moments as they emerge.

In this paper, we firstly contextualise the notion of post-qualitative research theoretically. Thereafter we situate the use of plugging-in as a particular post-qualitative methodological tool within the scope of this specific research. This is followed by a detailed account of the unfolding research process, showcasing how a post-qualitative approach can actively work towards the discovery of unexpected and transformative insights, practices, and things (Apple Dictionary, 2018). Implications of the research are then summarised in a concluding section.

\section{Post-qualitative research}

\section{Exploring theoretical perspectives}

Throughout the course of modern history, Western research has developed as a strong humanistic endeavour aimed at the development of knowledge deemed objective through processes of systematic investigation (Lather and St. Pierre, 2013). Scientific discourse has played a dominant part in research practice, placing great emphasis on rigorous research structure and an inherent 'hierarchical logic of representation' (MacLure, 2013: 658). Within a global, neoliberal context in which knowledge has become currency, these tendencies have been intensified to ensure economic profit. Research has become proceduralised and this often leads to investigative efforts having a restricted set of possible interpretive outcomes (Kuntz, 2015). According to Mignolo (cited in Zondi, 2018: 18), '[i]mperial reason as a dominant epistemic lens of mainstream science is in fact found and sustained by [proceduralised] methods and methodologies.' Thinking about methodology in the context of decoloniality, Zondi (2018: 20) has hence argued that 'the understanding of the method as a tool used to muzzle, to exclude, to denigrate, to silence, suffocate others' is crucial. Researchers must, he continued (2018: 20), 'use method as a form of combat ... as a tool for liberating thought ... not just rethinking methods but also unthinking them.'

But how can this be done in design research? What tools exist that can be used to unthink methods? According to St. Pierre (2014: 2-3), post-qualitative research explores 'the impossibility of an intersection between conventional humanist qualitative methodology and "the posts" ... [e.g.] postmodernism, poststructuralism, posthumanism.' Post-qualitative research involves a shift from 'logics of extraction to more relational means of identification' (Kuntz, 2015: 51). In line with 'the "post" ontologies' (Lather and St. Pierre, 2013: 631), postqualitative research can be characterised by three "Others" ... "Other" researcher subjectivities ... "Other" analytic practices ... [and] [a]n "Other" theory of change' (Lather, 2013: 639-640). Post-qualitative research poses a challenge to representational and binary logic as it attempts 
to explore how knowing and being can be practised responsibly in an entangled, performative manner (Lather, 2013).

Barad (2007: 185) has hence posed 'ethico-onto-epistem-ology' as a better-suited paradigm from which to do research. It is also within this paradigm that she has proposed diffraction as a useful methodological tool. Barad (2007) highlights the prevalence of using metaphors of optics when referring to processes of knowledge production. Not only is it common practice to refer to research findings as being illuminating, but the notion of reflection holds a firm position in qualitative research methodology. Both of these examples make the belief in the ability of humans, through language, to accurately represent an underlying, objective reality clear. Reflexivity, Barad (2007) argues, functions according the logic of representation. However, diffraction, being another optic metaphor, provides one with an alternative way of conceiving of knowledge production. From the perspective of physics, diffraction refers to the behaviour of waves when they encounter some form of interference or obstruction (Barad, 2007). Diffraction is thus a product of the intra-action ${ }^{3}$ between waves and the contingent factors, or agencies, which collaboratively cause their interference. The resulting diffraction pattern consequently 'maps where the effects of differences appear' (Haraway, 1992, as cited in Barad, 2007: 72) (emphasis in the original), rather than representing the objects or cause of the interference as reflection would. Barad (2007) hence proposes diffraction as a useful methodological tool in challenging representational logic in the doing of research.

In the light of this (to keep with optic metaphors), Kuntz (2015: 98) elaborates on the philosophical notion of parrhesia as a similarly diffractive methodological tool. He describes parrhesia as a 'critically materialist truth-telling that risks the very subjectivities through which we are known'. This concept has been theorised by Foucault (2015: 245), who holds that 'parrēsia will be the presence, in the person who speaks, of his own form of life rendered manifest, present, perceptible, and active as model in the discourse he delivers.' This implies that parrhesia embodies the process of, in everyday terms, practising what you preach. There exists an 'intimate link among inquiry and living' (Kuntz, 2015: 122); thus, truth is told when what we do (for example how we do research) becomes embodied in what we are. Truth, in this sense, is not a fixed entity that can be sought and ultimately delivered. It is a way of life. Truth becomes known when the inequality involved in 'one's relation to others, and one's relation to oneself' (Foucault, 1999) is openly risked and honestly negotiated. Honesty, in this sense, is crucial in that it asks of us to take responsibility for how what we are in the world ontologically designs what we know of/in the world and how that, in turn, ontologically designs what we become in circular fashion. Through such criticality, we can actively resist the present (Kuntz, 2015). We can risk the stable identities we have inherited through our past and, in the performance of such risk, can come to be differently on an ontological level (Kuntz, 2015). This reminds of Rancière's claim that emancipation ${ }^{4}$ is only possible through dissensus. Through

\footnotetext{
${ }^{3}$ Whereas interaction refers to the relationship between pre-existing, individual agencies, intra-action 'signifies the mutual constitution of entangled agencies' (Barad, 2007: 33).

${ }^{4} T$ The concept of emancipation as conceptualized by Rancière will be elaborated on in the following section.
} 
risking our stable sense of self, we can come to 'see' what the world has taught us to 'unsee' and, in 'seeing' (Lewis, 2013: 49), we can accordingly alter the dominant distribution of the sensible, so allowing truth to be told or, in other words, to be enacted or performed (Kuntz, 2015).

Parrhesia - truth-telling as research practice - thus works diffractively in that it develops intra-actively while simultaneously intervening in the material context in which it is situated (Kuntz, 2015). Moving from traditional research methodology to diffractive methodology does not, however, imply doing away with all the research concepts and methods that we have become so well acquainted with. Research should still involve 'knowing, thinking, measuring, theorising, and observing' (Barad, 2007: 90), but each action should be read through the other, so telling the truth regarding how their mutual entanglement participates in the materialdiscursive production of the world.

It is in the light of the above that a clearly defined methodological tool is valuable. Jackson and Mazzei's notion of plugging-in (2012) provides such a tool. They describe plugging-in as 'us[ing] theory to think with ... data (and us[ing] data to think with theory) in order to accomplish a reading of data that is both within and against interpretivism' (Jackson and Mazzei, 2013: 261). To plug theory into data and data into theory thus implies that the dominant understandings of what theory and data are and how they are usually used in relation to one another should be continuously resisted in practice. It does not mean getting rid of the wealth of existing philosophical and theoretical knowledge, nor that traditional data collection methods should not be used in research efforts, just that the causal relationship between these forces should be actively challenged in one's use thereof (Jackson and Mazzei, 2012). In the next section, we provide an example of how the methodological tool of plugging in was applied to a case of design research in the context of South African higher education.

\section{Contextualising plugging-in as methodological tool}

In line with post-qualitative research's aims to become the change one wants to make - rather than to study it from the outside - we set out to critically explore design education in the context of transformation at Stellenbosch University through practising design research/education geared at productive change within the institution. This involved critical negotiation of the processes of subjectification ${ }^{5}$ that transpired through the doing of a specific case of design/research/teaching in the context of the Visual Communication Design curriculum we were involved with. This specific case involved the design and facilitation of a range of three communication design projects with a select group of students over the course of one year. Data were collected traditionally through observation, written reflection, informal

\footnotetext{
${ }^{5}$ Subjectification, in this sense, refers to the processes involved in becoming posthuman subjects rather than humanist subjects defined in essentialist terms, i.e. in terms of binary opposites. According to Braidotti (2013: 49), posthuman subjects are 'relational subject[s] constituted in and by multiplicity, that is to say $\cdots$ subject[s] that work across differences and [are] also internally differentiated, but still grounded and accountable.'
} 
interviews, and documentation of visual communication design processes, but were, however, engaged with critically. As St. Pierre (2014: 4-5) has argued,

critique does not begin with the assumption that what exists is wrong or in error; rather, critique examines the assumptions that structure the discursive and the nondiscursive, the linguistic and the material, words and things, the epistemological and the ontological in order to foreground the historicity and, so, the unnatural nature of what exists.

All participants provided informed consent to participate in the research and ethical and institutional clearance was obtained from the institution. ${ }^{6}$

Throughout the unfolding of this research, the methodological tool of plugging-in served to keep the process in motion. It was the negotiation of awkward silences, the embodiment of paradox, and the struggles at translation - the ums and animated body language - that stood out in participants' processes of subjectification. In correspondence, theoretical concepts embodying similar tensions came to 'glow' (MacLure, 2013: 661). These included Barad's notion of diffraction (2007) and Foucault's concept of parrhesia or critical truth-telling (1999; 2015) as has been elaborated on in the previous section, as well as Rancière's idea of emancipation (1995; 1999) and the notion of serendipity as theorised by Ingraham (2019) on which more light will now be shed.

Whereas the concept of emancipation traditionally refers to the allowance of an inferior individual or social group into a supposedly dominant order (Biesta, 2010), Rancie re (1995) has described it as the active escape from a social minority. He proposes that in assuming a position of equality of intelligences (Biesta, 2010), those to be emancipated have the agency to deliberately negotiate the power differences operative in different regimes of sense. In this way they can thus effect potential for productive change (Biesta, 2010; Simons and Masschelein, 2010). Rancie 're's argument hence asserts that, in assuming equality as a different status quo from which to act - a different distribution of the sensible, or dissensus - the subjectivities that accordingly come into existence can embody the actualisation of the redistribution of the sensible and so engender productive future change or transformation.

The term 'serendipity' was first used in 1754 by Walpole who described it as 'accidental sagacity' (cited in Ingraham, 2019: 111). This definition positioned the concept in fairly instrumental, humanistic terms - the finding of unintentional, but productive, outcomes, was a product of the human ability to 'make sense of the hitherto insensible and unexpected' (Ingraham, 2019: 112). Ingraham (2019: 107), however, recently proposed that 'serendipity is fundamentally a mode of encounter, and one that can be as affective and autotelic as it is

\footnotetext{
${ }^{6}$ Pseudonyms have been used to refer to participants to protect their identities.
} 
cognitive and instrumental.' Understanding serendipity as affective ${ }^{7}$ encounter thus shifts our focus from the outcomes of serendipitous moments, to the forces that enable those moments. Serendipity, thus, 'is first about the encounter and possibility of entering into a new relation, and only thereafter about discovery and fortuity' (Ingraham, 2019: 112).

In line with Jackson and Mazzei's thought, we developed a range of 'analytical questions' (2012: 7) from the concepts that came to glow. Given the limited scope of a journal paper, we have, however, only explored the processes of subjectification that emerged in intra-action between one student and the primary researcher here. We also focused predominantly on Foucault's ideas surrounding parrhesia and Rancière's on emancipation to consider the potential value that a post-qualitative methodological approach could hold in the context of design research.

In line with Foucault's notion of parrhesia, a relevant analytical question to ask was how individual subjectivities have been risked (or have avoided risking themselves) throughout the process. In terms of Rancière's ideas surrounding emancipation, we were interested in how individual subjects have engaged with learning in terms of emancipation. We wanted to explore the inequalities that have potentially been assumed in efforts at emancipation and the moments of dissensus that have been affected throughout the course of the design education processes in question.

In the next section, we reflect on this specific case to demonstrate how a diffractive methodological approach has allowed for serendipitous encounters in an increasingly controlled research environment.

\section{Negotiating serendipity and risking the colonised self}

Project 1 was titled Local connections and aimed to engage students in experiential learning experiences through having to negotiate the design of a digital brochure for a local non-profit organisation - an organisation that has as goal to work toward 'creating income and economic growth through crafts in the [local] region' (Perold-Bull, 2015). Regardless of knowing that community interaction projects could accentuate existing inequalities between diverse participants, we decided to risk working with it in Project 1. It offered an opportunity for teaching and learning to transpire through the messy immediacy of real-life practice as opposed to at a safe academic distance. Serendipity as mode of affective encounter (Ingraham, 2019) cannot, we believe, emerge from any kind of predetermined situation. Our aim was thus to set up a situation where dissensus (Rancière, 2004) could be affected while still being able to contain the situation - to control the dosage of discomfort (Braidotti, 2016) - to some degree. In the words of Ingraham (2019: 115), we aimed to 'cultivat[e] an amenable affective environment in which [the serendipitous] might take hold.' The strategic problem directing the

\footnotetext{
${ }^{7}$ Affect, here, spurs from a Spinozist understanding thereof. It refers to 'an intensive force that draws bodies toward or away from one another in a precognitive relation that nevertheless establishes the possibilities for what those bodies can be or do $\cdots$ [w]e cannot know affects, only experience them in-act and then, retroactively, stammer for the language to describe them' (Ingraham, 2019: 108).
} 
project was to actively negotiate the schizophrenia ${ }^{8}$ (Deleuze and Guattari, 1987) involved in selling a business to potential funders (through the design of a promotional brochure) while simultaneously working towards productive social change (through contributing to greater goals of social justice and economic sustainability in a small, local way). Since sociocultural and economic power differences constituted a critical part of the project interaction/s, the project allowed productive opportunities to actively interrogate the often-uncomfortable relations between self and Other. Participants' conflicting affective responses to the project became visible through their body language, but they struggled to explicitly work with and through this during the course of the project itself. For example, Mandy's reaction to the project seemed to indicate that she needed confirmation from external forces to ensure productive agency of her own. In considering why she did not engage in playful, experimental research processes during the course of Project 1 (as she did in Project 2), ${ }^{9}$ she replied: 'We didn't really get the time' (2015). She also continually emphasised how she 'enjoyed' the project, so playing into the image of what she thought she was supposed to be rather than negotiating the aspects of her subjectivity that seemed to escape clear articulation (2015). Mandy's desire for consensus could further be seen in how she relied heavily on reaching out to and comparing herself with classmates in her processes of subjectification (2015). She seemed to protect herself from engaging in critical truth-telling (Foucault, 1999; 2015).

Project 1 did thus not seem to create adequate space for participants to engage in parrhesia. This could be because participants' focus remained on the representational end product - the brochures in the students' case and the research output in our case - as the 'things' that needed to effect productive change. In this sense, representation was used to protect our individual selves rather than being used as an opportunity to risk becoming other than we thought we were. Because visual representation tends to create the illusion of concrete form, it is easily associated with an embodiment of objectivity and truth and, as such, can be strongly aligned the binary logic characteristic of humanism. Binary thinking can thus be seen to skew the perception of design to the realm of representation of an already existing world order (Brassett, 2015; Escobar, 2012). What is then missed from view is the serendipitous aspect of design as that which transpires in between these entities. To borrow the words of Massumi (1992: 15), design does not lie in 'the genesis of the thing, nor in the thought of that genesis,

\footnotetext{
${ }^{8}$ Schizophrenia, which can also be described as simultaneously intense and often contradictory 'sensation[s], perception[s] and affect[s]' (Braidotti, 2010: 241) experienced by a subject, tends to be read as inherently negative when considered in terms of Cartesian logic. Understood in terms of Deleuze's philosophy of immanence, however, schizophrenia gestures to the productive potential that lies within the notion of a 'non-unitary subject' (Braidotti, 2010: 241).

${ }^{9}$ In order to accommodate the contemporary field of design's dynamic, processual nature, each project included some form of creative trigger - whether in the form of interaction with relevant stakeholders, watching a related movie, and/or reading applicable text - which led to diverse processes of critical thinking, creative play, visual experimentation, drawing and mark-making, idea generation, discussion and writing based on the specific topic in question. This kind of visual research process then had to be translated into formal communication design outcomes in each project's case.
} 
nor in the words written or spoken of it. It is in the process leading from one to the other' - in movement - that design comes into being.

Whereas the representational nature of the brochure designed in Project 1 seemed to allow students to hide behind the product, we used the design of Project 2 to create space in which students could practise tuning into difference in itself (Deleuze, 2004) in response to the schizophrenic processes of subjectification that emerged during the course of Project 1 . As educators, we tried to remain in process throughout our teaching. We tried to take into account each previous part of the process in our planning of what was to come next. We contextualised Project 2 in terms of negotiating the self as designer in contemporary society, and the students were asked to map their experiences through creative experimentation with and translation between text and image. We purposefully included directed visual exploration and mark making exercises as part of the project in order to break the existing moulds of what students thought a map should entail. For example, in the first part of this project, students were asked to represent the notions of identity and subjectivity respectively by folding, tearing and/or moulding a single sheet of paper in any way they deemed appropriate (Figure 1.1). The students were asked to use their sculptural pieces to make a range of two-dimensional marks on other sheets of paper, for example by tracing the outlines or using the piece as a stamp; they also had to start engaging in conversation regarding one another's understanding of the concepts based on the respective representations thereof (see Figures 1.2 to 1.4).

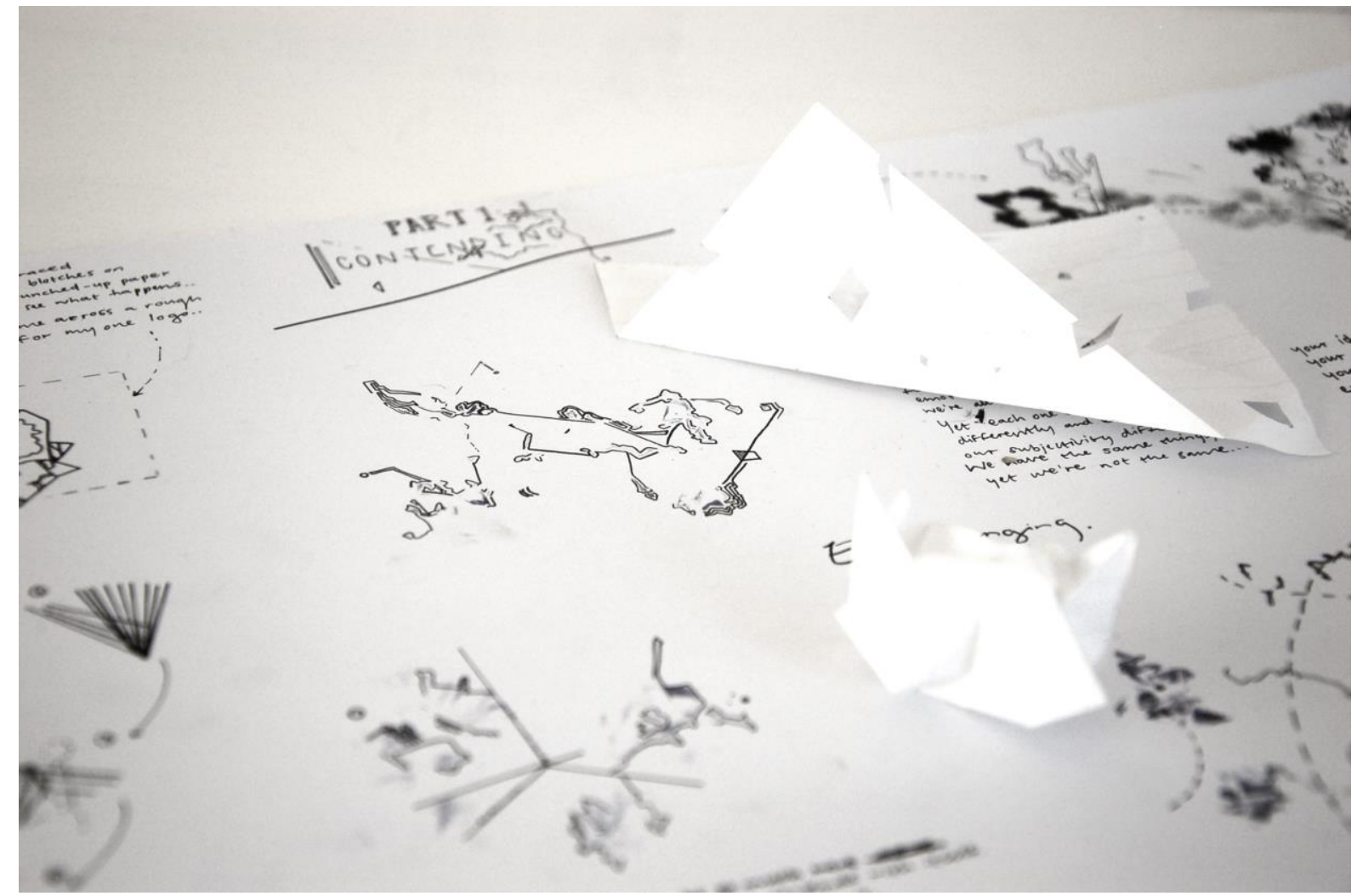

Figure 1.1: Project 2: Process development (representing identity and subjectivity through paper folding and visual mark making) (Source: Julie, 2015) 

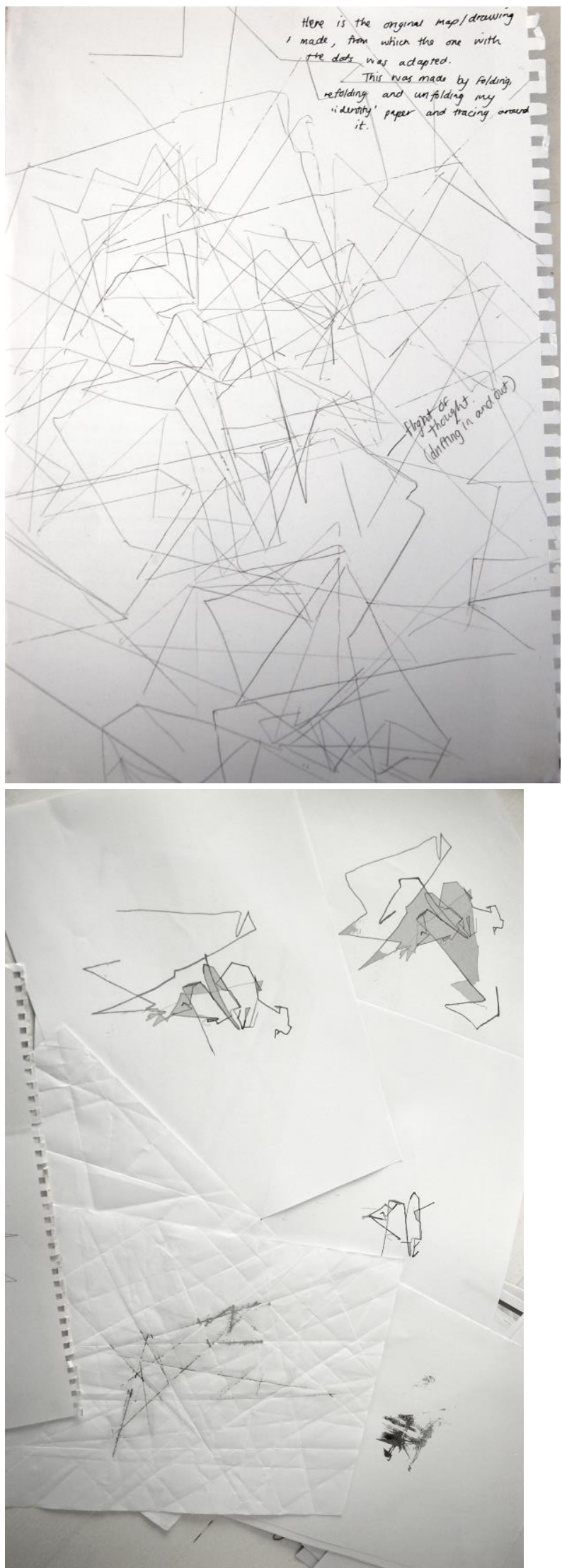

Figure 1.2-1.3: Project 2: Process development (directed visual exploration and mark making exercises with paper folding) (Source: Hannah, 2015) 


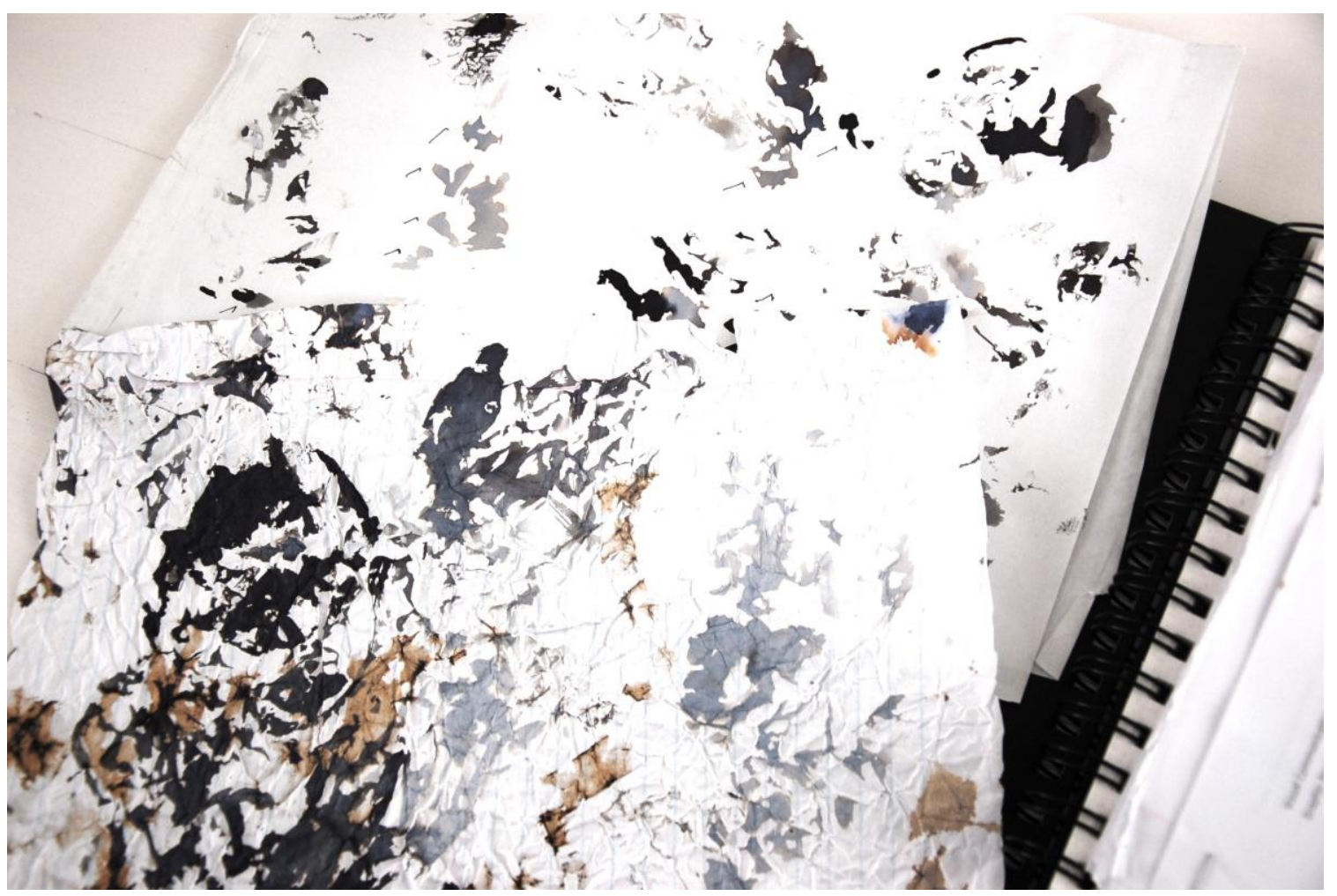

Figure 1.4: Project 2: Process development (directed visual exploration and mark making exercises with paper folding) (Source: Kim, 2015)

Mandy made strong comments on what she referred to as the unusual 'expressive' (2015) aspect of the project. She said: 'Expressing yourself is allowing yourself to have that place to play … And it inspires you, inspires your thoughts, inspires your creativity and it takes your design further instead of just like the first interesting thing you see online' (2015). This time around, the positive language Mandy used seemed to tap from future potential rather than reiterate a preceding status quo. She seemed to be claiming some power from within herself, rather than from external others. It can thus be asserted that the representational nature of design can simultaneously be geared towards opening up space for seeming opposites to gather force in serendipitous intra-action. For example, we were struck by the fluid manner in which Emma related the relation between her mind and body throughout the project experience. On the one hand, she translated making as devoid of thinking - 'you already have a visual representation of something without really thinking about it' (2015) - while, on the other hand, she reiterated that the resultant representational products or outcomes produced new concepts, thoughts and ideas - 'you just make something and then all of a sudden you start thinking about it in a different way' (Emma, 2015). (See Figures 2.1 to 2.3 for the documentation of this process.) 


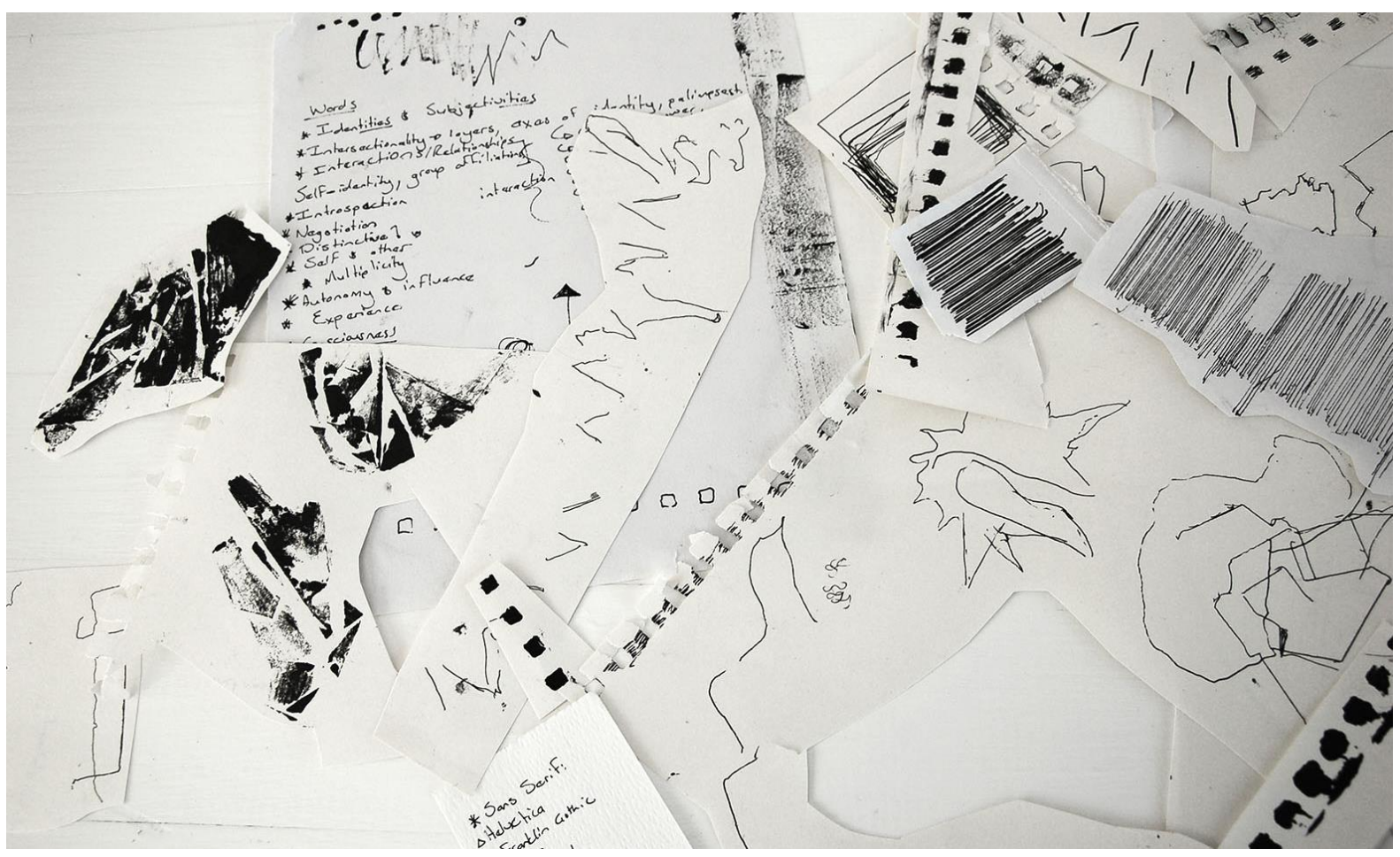

Figure 2.1: Project 2: Process development (directed visual exploration and mark making exercises) (Source: Emma, 2015)

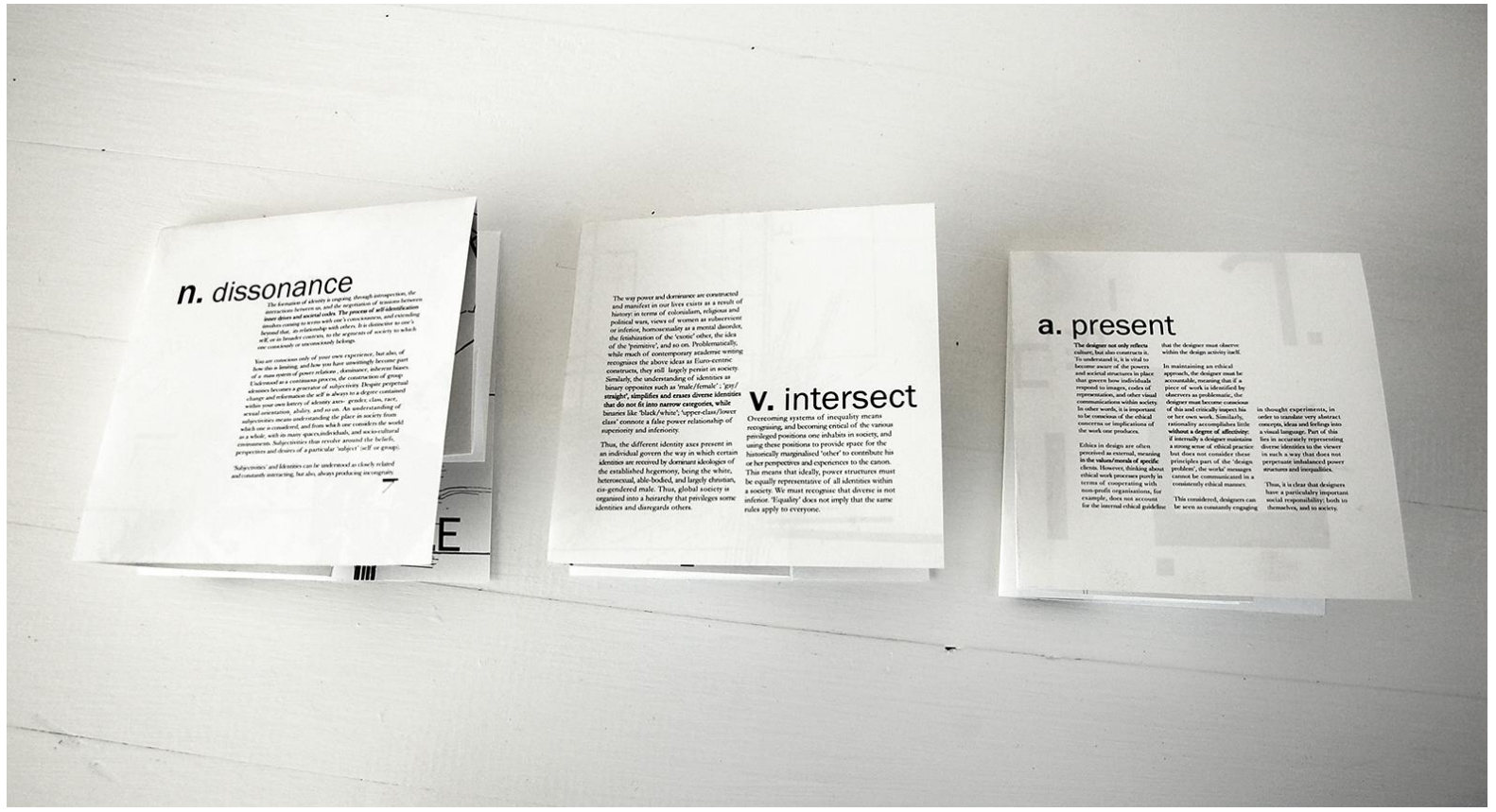

Figure 2.2: Project 2: Mapping meaning through typographic play (Source: Emma, 2015) 


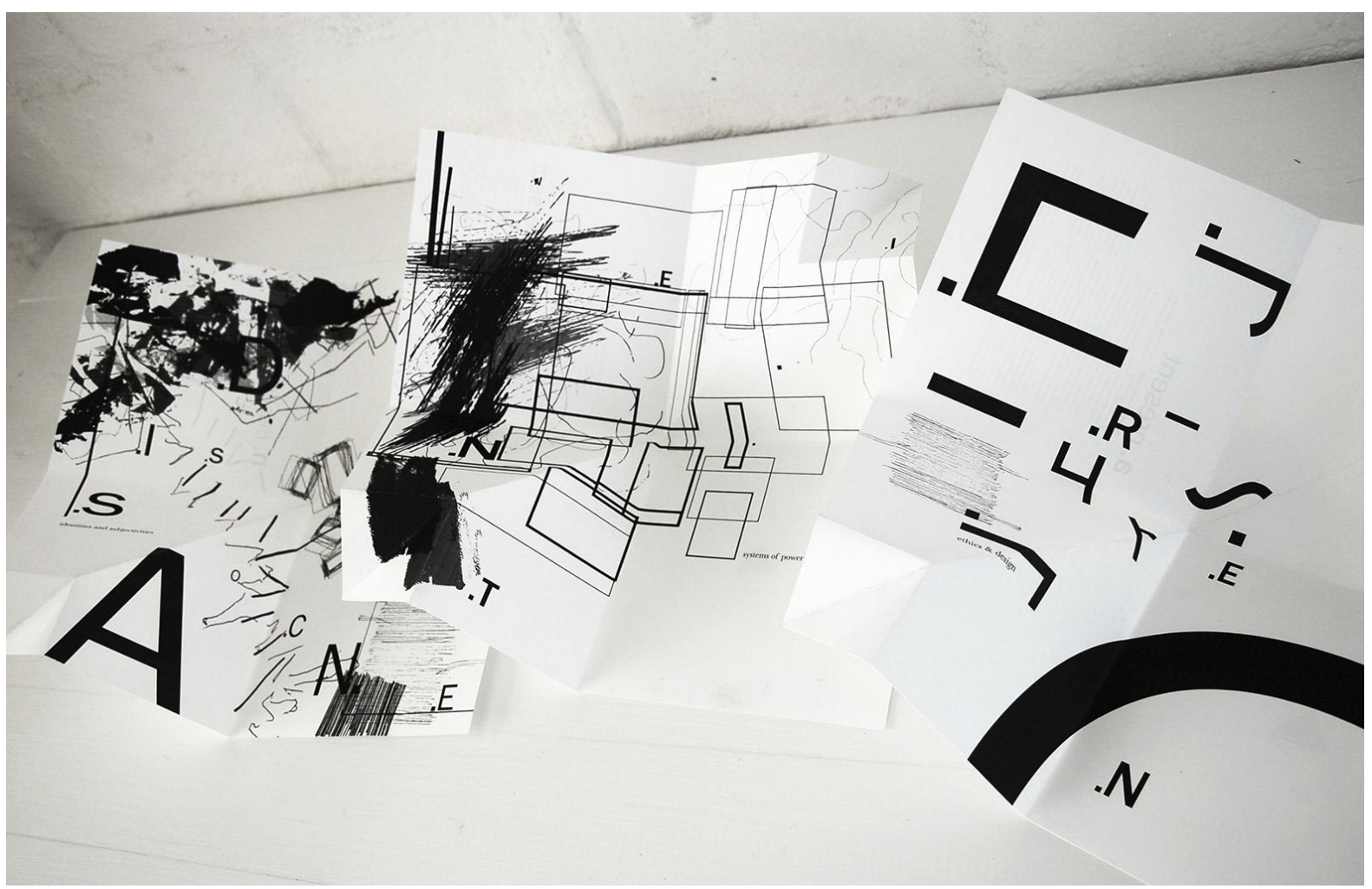

Figure 2.3: Project 2: Mapping meaning through typographic play (Source: Emma, 2015)

This seems to demonstrate that design holds great power in its ability to negotiate representation non-representationally, ${ }^{10}$ but in order for this to be done successfully the designer needs to be consciously aware of his/her use of representation so that its inherent ability to perpetuate existing narratives/discourses/ideologies through ontological design can be resisted actively in the present.

At this stage, a rich range of intra-active agencies had come to constitute the research process. The 2015 to 2016 student protests (Langa, 2017) contributed political force to the mix. ${ }^{11}$ As the drive towards decoloniality gained strength, we could sense transformative potential vibrating, but still struggled to claim it in our situated context. As mentioned before, each project that formed part of the larger research endeavour provided a renewed opportunity to respond to and resist what went before. We, therefore, used Project 3 to create

\footnotetext{
${ }^{10}$ Non-representational theory is a field of study that has emanated from work by Nigel Thrift in human geography. It places emphasis on 'not prioritising representations as the primary epistemological vehicles through which knowledge is extracted from the world,' but puts forth that representations are rather negotiated as 'active and affective interventions in a world of relations and movements' (McCormack, 2005: 122).

${ }^{11}$ The \#RhodesMustFall movement - '[a] student, staff and worker movement mobilising against institutional white supremacist capitalist patriarchy for the complete decolonization of UCT [the University of Cape Town]' (Rhodes MustFall, 2017) - was sparked on 9 March 2015 when a student threw human excrement at a statue of Cecil John Rhodes located centrally on the campus. Rhodes was an 'arch imperialist' (South African History Online [SAHO], 2017) in Africa and 'donor of the land on which the University of Cape Town was built (Ndebele, 2013). Similar activist movements were initiated at South Africa's other institutions of higher education and led to national protest action throughout 2015 and 2016 (Langa, 2017). These include \#StelliesMustFall at Stellenbosch University, as well as \#FeesMustFall and \#EndOutsourcing on a national level.
} 
an opportunity to consciously feel, experience, and live transformation in action. In the design of the project, we, therefore, tried to bring forces together that seemed to be geared towards effecting dissensus while simultaneously being able to allow a shared sense of community to emerge. The students were asked to engage with people other than themselves within the shared context of the institutional student community. In asking students to lay out the same text formally as well as experimentally through practising participatory design, ${ }^{12}$ we hoped to facilitate a collaborative exploration of engaging with representation non-representationally. We were interested in exploring if and how the students would tune in to individual differences collectively with others, and what transformative forces could become should they consequently resist and translate those differences representationally. In reflecting on Project 3 , Mandy wrote:

I'll admit that I was hesitant to speak to white students (as I am a coloured ${ }^{13}$ student) on topics of race and language because I had no idea how it would pan out. I've noticed how people tend to draw to others with a similar background because it's easier and comforting. I realised that I am the same. This encounter taught me a lot and I decided to add this theory to the list of questions in my interview [with a fellow white student] (2016) (our emphasis).

Mandy's reference to the acknowledgement of her own fear of the Other as theory was regarded as significant. Experiencing aspects of herself in others seemed to allow moments of Rancièrian emancipation to emerge. She seemed to act from a position of assumed equality, thus effecting dissensus in the reigning status quo. These moments seemed to be strengthened by diffracting the experience through experimental play with representational practice (see Figure 3).

\footnotetext{
${ }^{12}$ Participatory design refers to a democratic approach to design that involves mutual 'investigat[ion], reflect[ion] upon, understand[ing], establish[ment], develop[ment], and support [of] mutual learning processes as they unfold between participants in collective "reflection-in-action" during the design process' (Robertson and Simonsen, 2012: 5).

${ }^{13 .}$ Coloured' is a South African term used to refer to people of mixed race.
} 


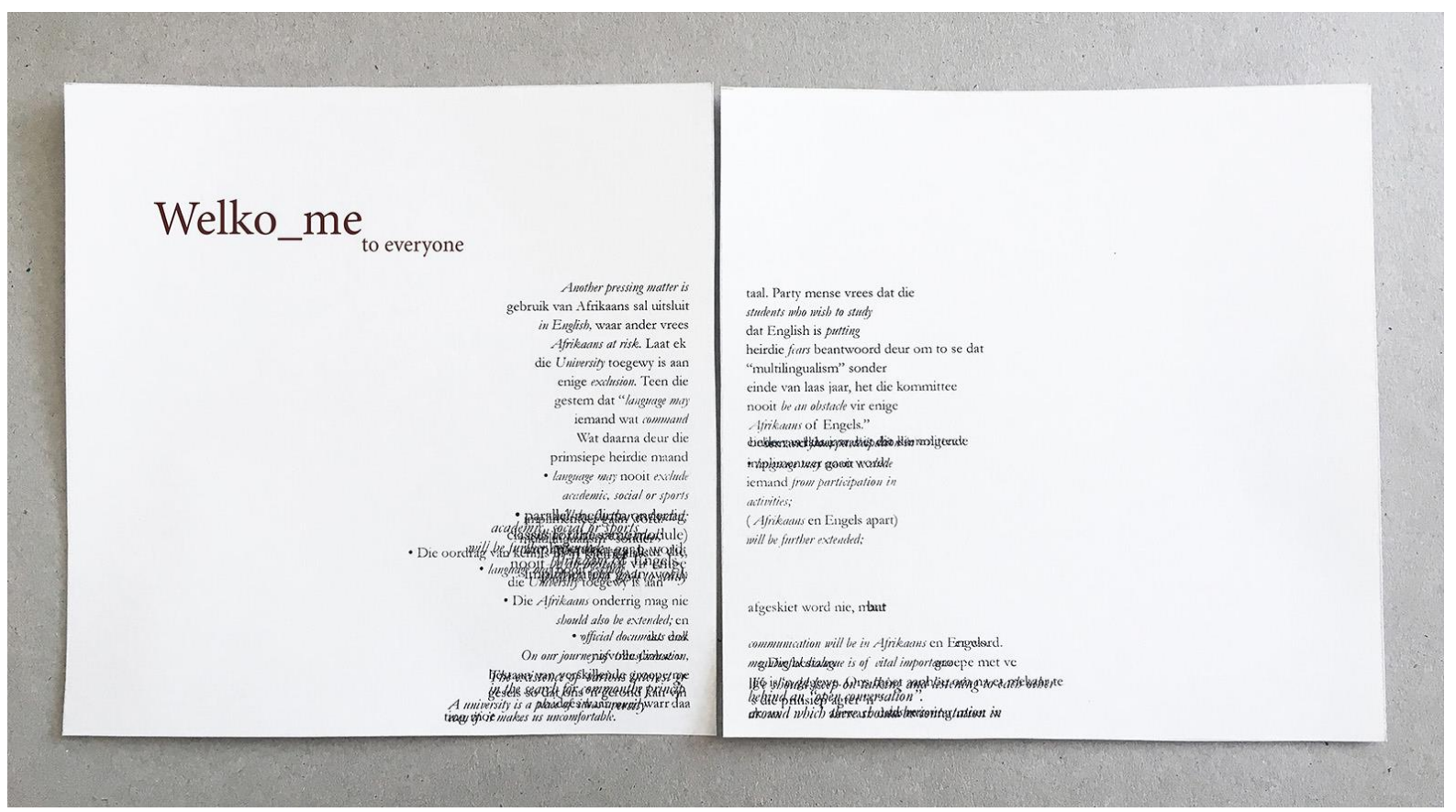

Figure 3: Project 3: Experimental layout (Source: Mandy, 2016)

In playing with typographic layout and composition, Mandy (2016) said, 'I found a way to work with the disunity and chaos of it all. I think the disunity in all the students' statements made the message stronger than if I had to use one person's opinion.' It seems that confidence became in her processes of subjectification, and she convincingly related her work as follows:

One who understands both English and Afrikaans, though a great effort to read, can comprehend what the text is saying. In a crit [critique session] a student related to the mess of language, stating that even when you understand both languages it still feels like that confusing mess when lecturers jump from English to Afrikaans. One who understands only English reads the English parts only and receives an entirely different message. The message in English can be interpreted as the students who do not understand Afrikaans [are] seen as a threat to the Afrikaans language, which is part of the insecure feelings of a non-Afrikaans-speaking student, along with feeling as though they are always confused and missing out on the whole picture $\cdots$ (2016).

She continued:

My interviewees, my classmates, my lecturer and myself had a unique experience when encountering this design, interpreting something unique due to their own experiences of language. I found this really intriguing and I'm glad my design could bring that forward (2016).

Playing with representation in non-representational ways seemed to allow for affective encounter in Mandy. She seemed to enter into new relations with herself as well as others and 
consequently serendipity seemed to come into the process and served to multiply the potential for personal emancipation and future transformation.

After completion of Project 3, we, as researchers, started the process of representing our research through writing. We soon realised the stronghold that extractive logic had on the writing process. We, likewise, needed serendipity in our writing process in order to challenge and resist the expert power inherently implied in us due to our position as researchers and teachers. After writing a first piece where we repeatedly plugged the range of theoretical concepts we were working with into glowing chunks of data, we were obliged - in being committed to parrhesia - to risk our attempt at working interpretively against interpretivism by plugging our text back into the thoughts of the participants with whom we had worked. We provided the relevant participants with the text. We gave them each a summarised overview of these thoughts and invited their input through dialogue in a second round of informal discussions (see Figure 4). These discussions were difficult for both the researchers and participants due to the assumed power relations between them, but in time each of the students seemed to take a strong personal stand in reaction to the unfolding conversation. It was as if they could hear the relevant theorists 'reading over [their] shoulder[s]' (Jackson and Mazzei, 2012: 7), encouraging them to resist the interpretive fragments of their own subjective experiences received from our perspective.

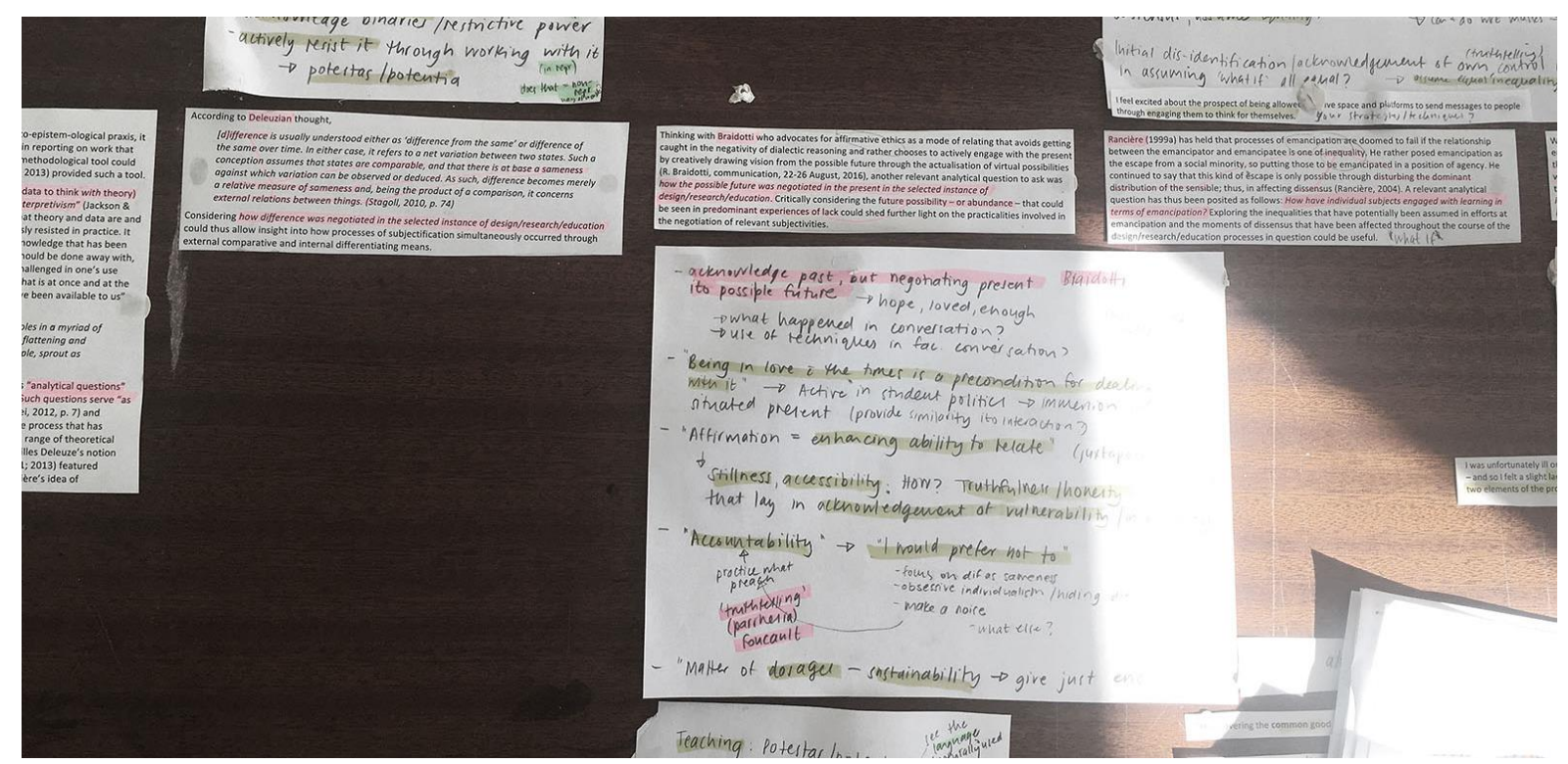

Figure 4: Excerpt from follow-up discussion map (Source: Perold-Bull, 2017)

For example, after we elaborated on Rancière's (2004) ideas regarding emancipation in discussion with Mandy, namely that he only regards emancipation as possible when approached from a position of assumed equality, she responded more fervently than before. 'Inequality is [said with emphasis] the reality. One needs to acknowledge it ... Black lives matter ... One needs to use your hierarchy [your superior power] to equalise' (Mandy, 2017).

We initially thought that she misunderstood our explanation of Rancière's ideas. We were, after all, providing her with a brief, summarised overview of quite complex philosophical 
thought. We tried to clarify, but she stood strong in her opinion, saying that '[o]ne has a responsibility to help those who do not have. Not to ask for gifts, but to help in using the available resources ... One needs to make a tangible difference' (2017). Plugging into Rancière's thought, Mandy's thoughts brought us to a halt. We were clearly trying to facilitate a process of getting her to a place of consensus, rather than resisting this urge and engaging in the dissensus that she was bringing to the table. Although we thought we were trying to resist the assumed power position of teacher/researcher throughout the research process, we came to experience what risking our colonised selves in fact means in an embodied manner. We were struggling with parrhesia (Foucault, 1999; 2015).

Consequently, we have carefully juxtaposed parts of our unfolding conversations with the original text written in order to allow a range of diffractive patterns - for a space for affective encounter, or serendipity (Ingraham, 2019) - to emerge. The result was two narratives that each make sense when read vertically on its own, but can also be read in crisscross fashion (see Figure 5), so mimicking a process of diffractive agencies through representational form and, in the process, allowing a third narrative to emerge non-representationally.

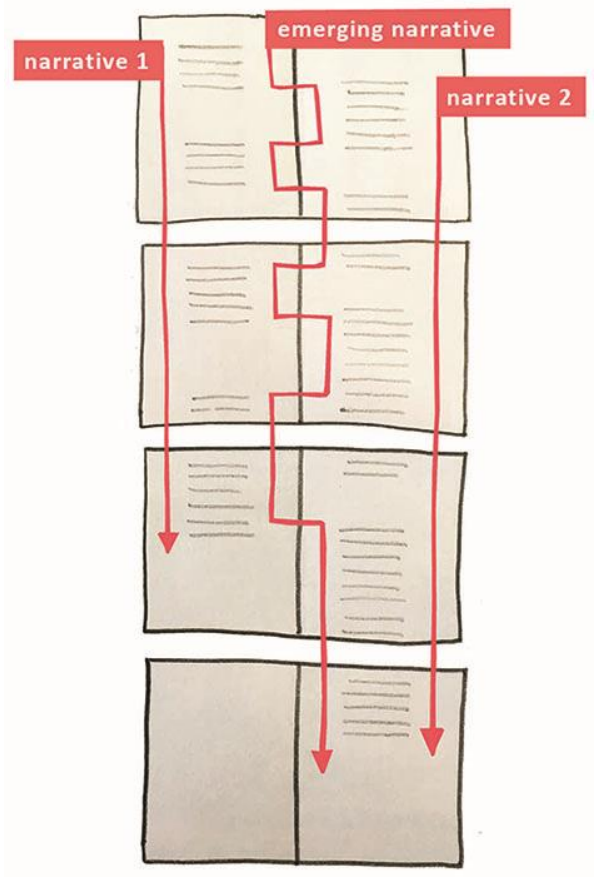

Figure 5: Structure of the emerging narrative/s (Source: Perold-Bull, 2018)

In structuring the text, we have made use of space, shape and colour as visual cues that can assist in directing (but not predetermining) the readers' attention throughout the reading experience (see Figure 6). 


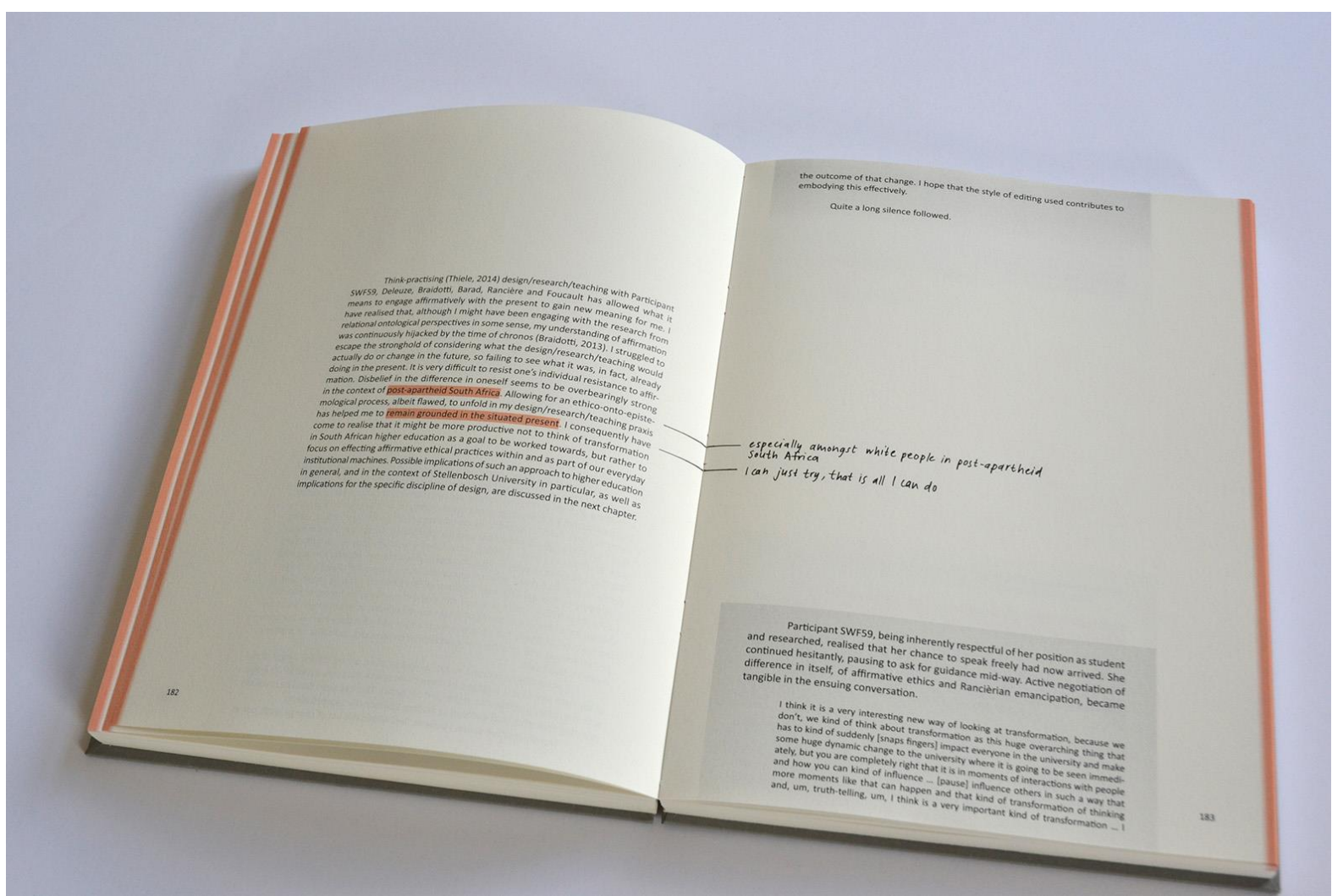

Figure 6: The final form of the narratives. (Source: Perold-Bull, 2018)

Whereas reading Narrative 1 (on the left-hand side of the double-page spread) has demonstrated the great difficulty experienced in trying to practise parrhesia, reading Narrative 2 (on the right-hand side of the double-page spread) in tandem has allowed for serendipitous moments of meaning generation to emerge progressively in-between. Accordingly, in forcing us to embody the positions of researchers, teachers, and students simultaneously, representational design practice allowed us, in the words of MacLure (2013: 666), to 'engage [more] fully with the materiality of language and its challenge to the workings of representation.' Processes of yet unknown future change - serendipitous moments - were allowed to develop through design research. This held great value in terms of negotiating productive transformation in the context of South African higher education.

\section{Tuning into serendipity: Concluding thoughts}

Through the specific case of design research in question, we quickly became aware that the application of the methodological tool of plugging-in necessarily changed the tool, and that any attempt at containing the way in which it was used necessitated active resistance to how it was used in that present moment. For example, we originally thought that plugging the same data chunks into each of the theoretical concepts that had come to glow throughout the research process would yield diverse interpretive possibilities for each data fragment. In trying to apply plugging-in through writing and typographic play, however, we found that the value of the methodological tool rather lay in structuring the research process in ways that facilitated 
continuous re-looking and re-thinking of a fairly narrow set of interpretive conclusions. This was ultimately what allowed for serendipity to become an active part of the research process.

Thus, taking a post-qualitative approach to design research firstly necessitates working with existing disciplinary structures to resist those very structures from the inside. This implies focusing on the processes that allow these structures to exist, rather than blind conformance to them. Secondly, creative play with representational practice is key in all aspects of the doing of research (e.g. as part of experimental fieldwork, data collection, data analysis, and presentation of findings). Allowing flexibility and adaptability in the research process is also important, as this allows the openness necessary for continual re-alignment between thinking and doing. Lastly, actively collapsing the distinction between assumed subject positions (e.g. designer, researcher and teacher in this case) can help to work towards serendipity or productive future change. Approaching research as teaching and teaching as research allowed for the emergence of opportunities for students to learn outside of the confines of the formal curriculum (i.e. opportunities in which participants had more freedom to act from an assumption of equality in negotiating their subjectivity and consequent learning). It allowed for the creation of time to openly question personal assumptions and interpretations with students through personal interaction and sharing. These are crucial ingredients in becoming aware of moments of serendipity transpiring within design research and education processes.

In conclusion, this case demonstrates how a post-qualitative approach to design research can facilitate experimentation with representational praxis in ways that challenge its traditional semiotic function. Such experience can contribute to subjects becoming more attuned to recognising and responding to serendipitous moments within their situated present. Consequently, it can be argued that the more such moments become felt through everyday design practices, the more receptive individuals can become to the potential for productive future change.

\section{Author biographies}

Karolien Perold-Bull is a lecturer and coordinator of the Visual Communication Design division in the Visual Arts Department, Stellenbosch University, South Africa. Her focus lies in design thinking, typographic, information, and experience design, and navigating the dynamic relationships between these fields and design philosophy and theory. In her research, she explores design from posthuman, new materialist perspectives. Her PhD focused on design education within the context of transformation and decolonisation in South African higher education.

Elmarie Costandius is an associate professor in Visual Arts and coordinates the MA in Visual Arts (Art Education) at Stellenbosch University, South Africa. She studied Information Design at the University of Pretoria and continued her studies at the Gerrit Rietveld Academy, Amsterdam, and completed a master's in Globalisation and Higher Education at the University 
of the Western Cape. Her PhD in Curriculum Studies (Stellenbosch University) focused on social responsibility and critical citizenship in art education.

\section{References}

Apple Dictionary. 2016. Cupertino: Apple Inc.

Barad, K. 2007. Meeting the universe halfway: Quantum physics and the entanglement of matter and meaning. Durham and London: Duke University Press.

Biesta, G. J. J. 2010. A new logic of emancipation: The methodology of Jacques Rancie re. Educational Theory, 60 (1): 39-59.

Braidotti, R. 2010. Schizophrenia. In Parr, A. (Ed). The Deleuze dictionary. Edinburgh: Edinburgh University Press, 240-243.

Braidotti, R. 2011. Nomadic theory: The portable Rosi Braidotti (Kindle edition). http://www.amazon.com (accessed 16 November 2015).

Braidotti, R. 2013. The posthuman. Cambridge and Malden: Polity Press.

Braidotti, R. 2016. The posthuman glossary. Lectures presented at Utrecht Summer School, University of Utrecht, The Netherlands. 22-26 August 2016.

Brassett, J. 2015. Poised and complex: The becoming each other of philosophy, design and innovation, in Brassett, J. \& Marenko, B. (Eds.). Deleuze and design. Edinburgh: Edinburgh University Press, 31-57.

Brassett, J. \& Marenko, B. 2015. Introduction, in Brassett, J. \& Marenko, B. (Eds.). Deleuze and design. Edinburgh: Edinburgh University Press, 1-30.

Chakrabarty, D. 2009. The climate of history: Four theses. Critical Inquiry, 35: 197-222.

Davis, H. \& Turpin, E. 2015. Introduction: Art \& death: Lives between the fifth assessment \& the sixth extinction. In Davis, H. \& Turpin, E (Eds.). Art in the Anthropocene: Encounters among aesthetics, politics, environments and epistemologies. London: Open Humanities Press. Online at: http://openhumanitiespress.org/books/download/Davis-Turpin_2015_ Art-in-the-Anthropocene.pdf [Accessed: 18 April 2017].

Deleuze, G. 2004. Difference and repetition. London and New York: Continuum.

Deleuze, G. \& Guattari, F. 1987. A thousand plateaus. Minneapolis: University of Minnesota Press.

Escobar, A. 2012. Notes on the ontology of design. Online at: http://sawyerseminar.ucdavis.edu/files/2012/12/ESCOBAR_Notes-on-the-Ontology-ofDesign-Parts-I-II-_-III.pdf [Accessed: 17 April 2017].

Faste, T. \& Faste, H. 2012. Demystifying 'design research': Design is not research, research is design. Paper presented at IDSA Education Symposium, Boston, 2012. Online at: http://www.haakonfaste.com/publications/demystifying_design_research.pdf [Accessed: 5 November 2018].

Foucault, M. 1999. Discourse and truth: The problematization of parrhesia. Online at: https://foucault.info/parrhesia/ [Accessed: 17 November 2018]. 
Foucault, M. 2015. Parrēsia. Critical Inquiry, 41 (2): 219-253. Online at: http://www.journals.uchicago.edu.ez.sun.ac.za/ [Accessed: 11 July 2017].

Ingraham, C. 2019. Serendipity as cultural technique. Culture, Theory and Critique, 60 (2): 107122.

Jackson, A. Y. \& Mazzei, L. A. 2012. Thinking with theory in qualitative research: Viewing data across multiple perspectives. Oxon: Routledge.

Jackson, A. Y. \& Mazzei, L. A. 2013. Plugging one text into another: Thinking with theory in qualitative research. Qualitative Inquiry, 19 (4): 261-271.

Kuntz, A. M. 2015. The responsible methodologist: Inquiry, truth-telling, and social justice. Walnut Creek, California: Left Coast Press.

Langa, M. (Ed.). 2017. \#Hashtag: An analysis of the \#FeesMustFall movement at South African universities. Johannesburg and Cape Town: Centre for the Study of Violence and Reconciliation.

Lather, P. 2013. Methodology-21: What do we do in the afterward? International Journal of Qualitative Studies in Education, 26 (6): 634-645.

Lather, P. \& St. Pierre, E.A. 2013. Post-qualitative research. International Journal of Qualitative Studies in Education, 26 (6): 629-633.

Lewis, T. E. 2013. Jacques Rancière's aesthetic regime and democratic education. Journal of Aesthetic Education, 47 (2): 49-70.

MacLure, M. 2013. Researching without representation? Language and materiality in postqualitative methodology. International Journal of Qualitative Studies in Education, 26 (6): 658-667.

Massumi, B. 1992. A user's guide to capitalism and schizophrenia: Deviations from Deleuze and Guattari. Cambridge and London: The MIT Press.

McCormack, D. P. 2005. Diagramming practice and performance. Environment and Planning D: Society and Space, 23: 118-147.

Murris, K. 2016. \#Rhodes must fall: A posthumanist orientation to decolonising higher education institutions. South African Journal of Higher Education, 30 (3): 274-294.

Ndebele, N. 2013. Reflections on Rhodes: A story of time. University of Cape Town. Online at: https://www.news.uct.ac.za/article/-2015-03-19- reflections-on-rhodes-a-story-of-time [Accessed: 18 July 2017].

Perold-Bull, K. 2015. Project brief. Stellenbosch: Stellenbosch University.

Rancière, J. 1995. On the shores of politics. London and New York: Verso.

Rancière, J. 1999. Disagreement: Politics and philosophy. Minneapolis and London: University of Minnesota Press.

Rancière, J. 2004. The philosopher and his poor. Durham: Duke University Press.

Rhodes Must Fall. 2017. Online at: https://www.facebook.com/pg/ RhodesMustFall/about/?ref=page_internal [Accessed: 18 July 2017].

Robertson, T. \& Simonson, J. 2012. Challenges and opportunities in contemporary participatory design. Design Issues, 28 (3): 3-9. 
Shay, S. \& Peseta, T. 2016. A socially just curriculum reform agenda. Teaching in Higher Education, 21 (4): 361-366.

Simons, M. \& Masschelein, J. 2010. Governmental, political and pedagogic subjectivation: Foucault with Rancie re. Educational Philosophy and Theory, 42 (5-6): 588-605.

South African History Online. 2017. Cecil John Rhodes. Online at: http://www.sahistory.org.za/people/cecil-john-rhodes [Accessed: 18 July 2017].

St. Pierre, E. A. 2014. A brief and personal history of post-qualitative research: Toward "post inquiry". Journal of Curriculum Theorizing, 30 (2): 2-19.

Willis, A. M. 2006. Ontological designing: Laying the ground. Design Philosophy Papers, 4 (2): 69-92.

Zondi, S. 2018. Decolonising International Relations and its theory: A critical conceptual meditation. Politikon, 45 (1): 16-31. 